\title{
Identifikasi Faktor Yang Mempengaruhi Kinerja Usaha Mikro Kecil Dan Menengah (UMKM)
}

\author{
Mona Permatasari Mokodompit ${ }^{1}$, Syarifuddin $^{1}$, Sutiana Mutia ${ }^{2}$ \\ ${ }^{1}$ Program Studi Akuntansi, Universitas Papua \\ ${ }^{2}$ Alumni Program Studi Akuntansi, Universitas Papua
}

Received: Desember 2018; Accepted: Januari 2019; Published: Maret 2019

\begin{abstract}
Abstrak
Penelitian ini bertujuan untuk menguji pengaruh faktor internal dan faktor eksternal secara parsial terhadap kinerja usaha Mikro Kecil dan Menengah (UMKM) sektor industri di Kabupaten Manokwari. Data penelitian diperoleh dengan memberikan kuesioner dan melakukan wawancara kepada 34 pemilik UMKM sektor industri di Kabupaten Manokwari. Data kemudian dianalisis menggunakan alat analisis regresi linear berganda. Hasil uji dalam penelitian ini menunjukkan bahwa faktor internal tidak berpengaruh signifikan terhadap kinerja UMKM. Sedangkan, faktor eksternal berpengaruh signifikan terhadap kinerja UMKM.
\end{abstract}

Kata kunci: kinerja usaha mikro kecil dan menengah, faktor internal, faktor eksternal

\begin{abstract}
This study aims to examine the influence of internal and external factors partially on the performance of Micro, Small and Medium Enterprises (MSMEs) of industrial sector in Manokwari Regency. Research data is obtained by giving questionnaires and interviews to 34 MSMEs owners of industrial sector in Manokwari Regency. The data was then analyzed by using a multiple linear regression analysis tool. The results of this study indicate that internal factors have no significant influence on the performance of MSMEs. Whereas, external factors have a significant influence on the performance of MSMEs.
\end{abstract}

Keywords: performance of micro, small and medium enterprises, internal factors, external factors

How to Cite: Mokodompit, M.P., Syarifuddin, Mutia, S. (2019). Identifikasi Faktor Yang Mempengaruhi Kinerja Usaha Mikro Kecil Dan Menengah (UMKM). JFRES: Journal of Fiscal and Regional Economy Studies, 2 (1), 87-92.

\footnotetext{
Corresponding author:

E-mail: m.mokodompit@unipa.ac.id
} 


\section{PENDAHULUAN}

Usaha Mikro Kecil dan Menengah (UMKM) saat ini merupakan bagian penting dalam perkembangan keuangan suatu bangsa. Sebagian ekonom terkenal menyatakan bahwa kehadiran UMKM merupakan mesin pengembang dalam sebagaian besar ekonomi dunia (Senzu \& Ndebugri, 2018). Di Indonesia, UMKM memiliki peran strategis dalam pembangunan ekonomi nasional. Data Badan Pusat Statistik (BPS) menunjukkan bahwa jumlah penyerapan tenaga kerja dari sektor UMKM lebih besar dibandingkan sektor lain, dan jumlah pertumbuhan UMKM pun meningkat cukup pesat dari tahun ke tahun (Mokodompit \& Usman, 2018). Meningkatnya jumlah UMKM merupakan suatu bentuk ketangguhan UMKM dalam bertahan dari beberapa gelombang krisis yang pernah terjadi di Indonesia. Pencapaian yang luar biasa dan potensi yang besar dari UMKM tersebut tentunya tidak luput dari berbagai tantangan yang harus dihadapi setiap UMKM, termasuk UMKM sektor industri.

Pada tahun 2017, data BPS mencatat bahwa kontribusi sektor industri terhadap perkonomian nasional masih mendominasi dan menjadi urutan ke-empat dunia, yakni sebesar $20.16 \%$ dari Produk Domestik Bruto (PDB) Indonesia yang mencapai Rp 13.588,8 triliun (Databoks, 2018). Meskipun demikian, salah satu tantangan yang harus dihadapi UMKM sektor industri adalah kemampuan untuk mempertahankan dan menjaga keberlangsungan usaha. Apalagi saat ini dunia telah memasuki era revolusi industri 4.0. Oleh sebab itu, perlu adanya kepekaan dan intropeksi yang dilakukan perusahaan agar dapat mendeteksi posisinya di tengah perkembangan ilmu pengetahuan dan teknologi.

Tantangan yang sama juga di hadapi oleh para pelaku UMKM sektor industri di Kabupaten Manokwari Provinsi Papua Barat. Sejak Manokwari menjadi ibukota Provinsi Papua Barat di tahun 2002, aktivitas perekonomian daerah semakin meningkat seiring dengan meningkatnya mobilitas barang dan jasa yang ditandai dengan peningkatan jumlah investor yang menanamkan modalnya di berbagai sektor ekonomi dan skala usaha (Lembaga Penelitian UNIPA, 2012).

Perkembangan ekonomi serta adanya persaingan tentunya mengharuskan semua jenis kegiatan usaha untuk bisa bersaing dengan baik. Ketua Kamar Dagang dan Industri Indonesia (Kadin) Provinsi Papua Barat, Yusuf Saway, mengatakan kekayaan alam di Provinsi Papua Barat yang cukup melimpah menjadikan potensi UMKM dan produk yang dihasilkan cukup banyak dan tersebar di setiap wilayah Kabupaten/Kota (Antara News, 2016). Dengan demikian, usaha sektor industri merupakan salah satu sektor yang berpotensi sebagai pendorong pertumbuhan ekonomi dan kesejahteraan masyarakat di Provinsi Papua Barat, tak terkecuali di Kabupaten Manokwari. Pengukuran kinerja UMKM merupakan suatu metode yang dapat digunakan dalam melihat kemampuan usaha dalam persaingan. Hal ini dilakukan dengan menganalisis faktor-faktor yang mempengaruhi dalam berwirausaha, baik faktor internal maupun faktor eksternal. Kedua faktor internal dan faktor eksternal ini membantu perusahaan dalam menganalisis dan merencanakan strategi yang diperlukan perusahaan untuk meningkatkan posisi kompetitif perusahaan di masa depan (Capps \& Glissmeyer, 2012).

Faktor internal merupakan dasar guna untuk membangun tujuan dan strategi dalam menciptakan kekuatan dan mengatasi kelemahan organisasi (David, 2009). Zimmerer et. al. (2008) menjelaskan bahwa terdapat dua macam faktor internal, yakni faktor internal positif dan faktor internal negatif. Faktor internal positif (keterampilan atau pengetahuan, citra publik yang positif, tenaga penjualan yang berpengalaman, pelanggan yang loyal, dsb) merupakan faktor internal yang dapat digunakan dalam mencapai misi, sasaran dan tujuan perusahaan. Sedangkan faktor internal negatif (kekurangan modal, kekurangan pekerja terampil, tidak mampu menguasai teknologi, dan lokasi yang tidak strategis) merupakan faktor internal yang harus dihindari perusahaan agar tidak menghambat dalam pencapaian tujuan perusahaan. Indikator faktor internal meliputi aspek sumber daya manusia, aspek keuangan, aspek teknis produksi dan operasi serta aspek pasar dan pemasaran (Sandra dan Purwanto, 2015).

Beberapa penelitian terdahulu membuktikan bahwa faktor internal berpengaruh terhadap kinerja UMKM. Hasil penelitian Munizu (2010) menunjukkan bahwa faktor internal (aspek sumber daya manusia, aspek keuangan, aspek produksi/operasional dan aspek pasar dan pemasaran) memiliki pengaruh yang signifikan dan positif terhadap kinerja UMK. Penelitian dari Hati dan Irawati (2017) juga menunjukkan bahwa faktor internal berpengaruh signifikan terhadap kinerja UMKM. Bertentangan dengan 
hasil penelitian diatas, Purwidiati dan Rahayu (2017) menemukan bahwa faktor internal tidak sepenuhnya berpengaruh positif terhadap kinerja Industri Kecil dan Menengah (IKM). Meskipun terdapat perbedaan hasil, namun hipotesis pertama yang diajukan dalam penelitian adalah sebagai berikut:

$\mathrm{H}_{1}$ : Faktor internal berpengaruh signifikan terhadap kinerja UMKM.

Faktor eksternal adalah faktor yang mempengaruhi perusahaan dalam menentukan arah dan tindakan yang akan dilakukan perusahaan (Pearce \& Robinson, 2011). Perusahaan dalam mencapai tujuan perlu menganalisis faktor-faktor yang paling berpengaruh terhadap perusahaan dengan melihat peluang yang berada di lingkungan eksternal, serta melakukan penyesuaian dengan mempertimbangkan keadaan dan kompetensi inti perusahaan (Zimmerer et. al., 2008). Adapun faktor eksternal dapat diukur dengan melihat empat indikator berikut: (1) aspek kebijakan pemerintah, yakni meliputi kegiatan pembinaan melalui dinas terkait, peraturan dan regulasi pro bisnis, penyiapan lokasi usaha dan penyediaan informasi; (2) aspek sosial, budaya dan ekonomi, yakni meliputi tingkat pendapatan masyarakat, tersediannya lapangan kerja, iklim usaa dan investasi, dan pertumbuhan ekonomi; (3) aspek peran lembaga terkait, yakni meliputi bantuan permodalan dari lembaga terkait, teknis/pelatihan, pendampingan, monitoring dan evaluasi (Munizu, 2010). Hasil penelitian dari Munizu (2010) menunjukkan bahwa faktor eksternal (aspek kebijakan pemerintah, aspek sosial budaya dan ekonomi, dan aspek peranan lembaga terkait) memiliki pengaruh yang signifikan dan positif terhadap kinerja UMK. Namun, penelitian dari Hati dan Irawati (2017) menunjukkan bahwa faktor eksternal tidak berpengaruh signifikan terhadap kinerja UMKM. Hasil penelitian tersebut juga didukung oleh Purwidianti dan Rahayu (2017) yang menyatakan bahwa faktor eksternal tidak memiliki pengaruh positif terhadap kinerja usaha IKM. Berdasarkan urian tersebut, maka hipotesis kedua yang diajukan dalam penelitian ini adalah sebagai berikut:

$\mathrm{H}_{2}$ : Faktor eksternal berpengaruh signifikan terhadap kinerja UMKM.

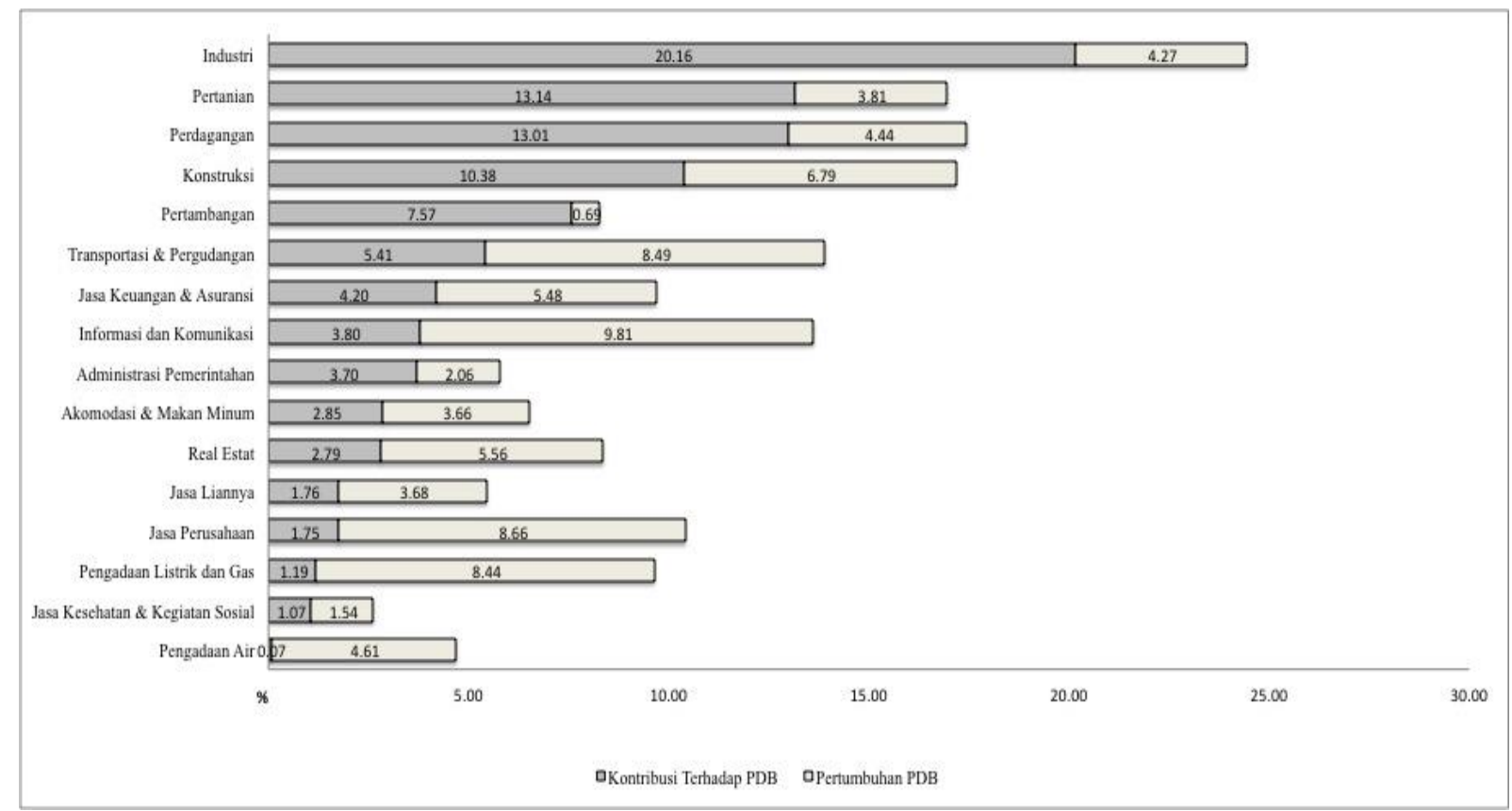

Sumber: Data diolah, 2018

Gambar 1. Kontribusi dan Pertumbuhan Sektoral PDB Indonesia Tahun 2017

\section{METODE PENELITIAN}

Data penelitian bersumber dari data primer yang diperoleh dengan melakukan wawancara serta memberikan kuesioner kepada responden penelitian yakni pelaku UMKM sektor industri di Kabupaten Manokwari. Kuesioner yang digunakan menggunakan pengukuran skala likert dengan skor $1-5$ yang disesuaikan dengan masing-masing jawaban responden terhadap pernyataan pada kuesioner. Uji validitas dan uji reliabilitas instrumen penelitian, serta uji asumsi klasik dilakukan sebelum data penelitian dianalisis. Terdapat 34 kuesioner yang dianalisis 
menggunakan uji regresi linear berganda. Model persamaan regresi penelitian ini adalah sebagai berikut:

$$
\mathrm{KNJ}=\alpha+\beta_{1} \mathrm{FI}_{1}+\beta_{2} \mathrm{FE}_{2}+\varepsilon
$$

Keterangan:

$$
\begin{array}{ll}
\text { KNJ } & =\text { Kinerja UMKM } \\
\text { FI } & =\text { Faktor Internal } \\
\text { FE } & =\text { Faktor Eksternal }
\end{array}
$$

$$
\begin{array}{ll}
\alpha & =\text { Konstanta } \\
\beta_{1}, \beta_{2} & =\text { Koefisian Regresi } \\
\varepsilon & =\text { Error }
\end{array}
$$

\begin{tabular}{|c|c|}
\hline Definisi & Pengukuran \\
\hline $\begin{array}{l}\text { Variabel Independen: } \\
\text { Faktor Internal } \\
\text { Faktor internal merupakan faktor } \\
\text { yang menjadi dasar guna } \\
\text { membangun tujuan dan strategi } \\
\text { dalam menciptakan kekuatan dan } \\
\text { mengatasi kelemahan organisasi } \\
\text { (David, 2009). }\end{array}$ & $\begin{array}{l}\text { - Aspek SDM (penyeleksian, pengalaman kerja, pemberian } \\
\text { pengahargaan, pembagian tugas) } \\
\text { - Aspek Keuangan (modal sendiri, modal pinjaman, kemampuan usaha } \\
\text { dalam perolehan laba) } \\
\text { - Aspek Produksi dan Operasional (penggunaan bahan baku, } \\
\text { ketersediaan dan pemeliharaan mesin/peralatan, pemanfaatan teknologi } \\
\text { modern) }\end{array}$ \\
\hline $\begin{array}{l}\text { Faktor Eksternal } \\
\text { Faktor eksternal adalah faktor } \\
\text { yang mempengaruhi perusahaan } \\
\text { dalam menentukan arah dan } \\
\text { tindakan yang akan dilakukan } \\
\text { perusahaan (Pearce \& Robinson, } \\
\text { 2011). }\end{array}$ & $\begin{array}{l}\text { - Aspek Pasar dan Pemasaran (segmentasi pasar, kualitas produk, } \\
\text { penetapan harga, kegiatan promosi) } \\
\text { - Aspek Kebijakan Pemerintah (pembinaan, penyediaan informasi, akses } \\
\text { ijin usaha) } \\
\text { - Aspek Sosial dan Ekonomi (tingkat pendapatan masyarakat, kebutuhan } \\
\text { konsumen dan budaya daerah, karakteristik masyarakat) } \\
\text { - Aspek Peranan Lembaga Terkait (bantuan permodalan, pelatihan, } \\
\text { monitoring) }\end{array}$ \\
\hline $\begin{array}{l}\text { Variabel Dependen: } \\
\text { Kinerja UMKM } \\
\text { Kinerja adalah hasil atau tingkat } \\
\text { keberhasilan seseorang secara } \\
\text { keseluruhan }\end{array}$ & $\begin{array}{l}\text { - Peningkatan penjualan } \\
\text { - Peningkatan laba } \\
\text { - Peningkatan modal usaha } \\
\text { - Peningkatan pelanggan } \\
\text { - Tujuan dan target usaha tercapai } \\
\text { - Kemampuan laba dalam memenuhi kebutuhan }\end{array}$ \\
\hline
\end{tabular}

Variabel independen penelitian ini adalah faktor internal dan faktor eksternal, dan variabel dependennya adalan kinerja UMKM. Untuk definisi operasional dan pengukuran variabel disajikan pada Tabel 1 .

Tabel 1. Definisi Operasional dan Pengukuran Variabel

\section{Sumber: Data diolah, 2018}

\section{HASIL DAN PEMBAHASAN}

Responden penelitian ini adalah 34 pelaku UMKM sektor industri di Kabupaten Manokwari yang mayoritas bergerak di usaha depot air minum seperti yang dapat dilihat pada Gambar 2. Hasil uji validitas dan reliabilitas terhadap kuesioner yang dilakukan sebelum data dianalisis menunjukkan nilai signifikansi kurang dari 0,05 dan nilai cronbrach alpha diatas 0,7. Dengan demikian maka kuesioner dapat dikatakan valid dan reliabel. Selanjutnya sebelum data dianalisis menggunakan regresi liner berganda, dilakukan uji asumsi klasik (uji normalitas, uji heteroskedastisitas, dan uji multikolinearitas) terlebih dahulu. Hasil uji normalitas menunjukkan bahwa nilai signifikansi Kolmogorov-Smirnov sebesar 0,986 yang mana lebih besar dari 0,05 , sehingga dapat dikatakan bahwa data terdistribusi normal. Untuk uji heteroskedastisitas menunjukkan nilai signifikansi semua variabel independen diatas 0,05 , yakni variabel faktor internal sebesar 0,318 dan eksternal sebesar 0,081, ini berarti bahwa tidak ada masalah heteroskedastisitas. Hasil uji multikolinearitas didapati bahwa nilai VIF untuk variabel faktor internal $(1,678)$ dan eksternal $(1,678)$ kurang dari 10 dan nilai tolerance variabel faktor internal $(0,596)$ dan eksternal $(0,596)$ diatas 0,10 , yang berarti bahwa tidak terdapat multikolinearitas antar variabel independen. 


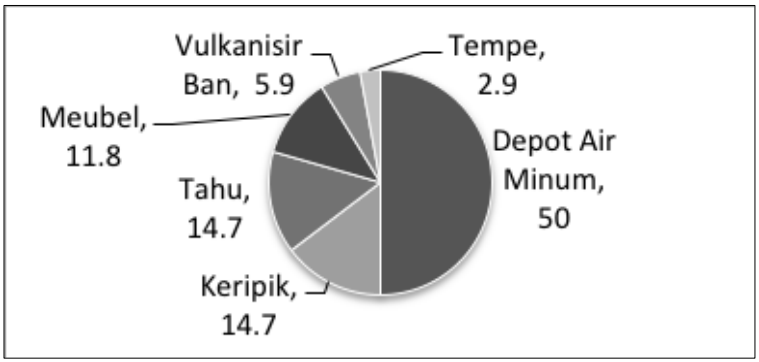

Sumber: Data diolah, 2018

Gambar 2. Deskripsi Usaha Responden

Hasil analisis regresi linear berganda disajikan pada Tabel 2, dimana ditunjukkan bahwa nilai adjusted $\mathrm{R}$ square sebesar 0,544. Ini berarti bahwa 54.4\% variasi kinerja UMKM dapat dijelaskan oleh variasi variabel faktor internal dan faktor eksternal. Sedangkan sisanya sebesar $45.6 \%$ disebabkan oleh faktor lain diluar model. Kemudian untuk uji kelayakan model melalui uji F menunjukkan nilai signifikansi sebesar 0,000 yang mana lebih kecil dari 0,05 . Sehingga dapat disimpulkan bahwa model penelitian ini layak atau dengan kata lain variabel faktor internal dan faktor eksternal mampu menjelaskan variabel kinerja UMKM.

Tabel 2. Hasil Uji Hipotesis

\begin{tabular}{|c|c|c|c|c|c|}
\hline Model & & Coefficients & $\mathbf{t}$ & Sig. & Hasil \\
\hline (Constant) & & 1,953 & 0,515 & 0,610 & \\
\hline Faktor Internal & & 0,072 & 1,162 & 0,254 & H1 Ditolak \\
\hline Faktor Eksternal & & 0,398 & 4,146 & 0,000 & H2 Diterima \\
\hline F-Test & 20,699 & & & 0,000 & \\
\hline Adjusted R Square & 0,544 & & & & \\
\hline
\end{tabular}

\section{Sumber: Data diolah, 2018}

Pengujian hipotesis satu dalam penelitian ini bertujuan untuk membuktikan bahwa faktor internal berpengaruh signifikan terhadap kinerja UMKM. Faktor internal diuji dengan melihat empat dimensi sebagai indikator yakni aspek SDM, aspek keuangan, aspek produksi dan operasional, serta aspek pasar dan pemasaran. Dapat dilihat hasil pengujian hipotesis satu $\left(\mathrm{H}_{1}\right)$ pada Tabel 2 menunjukkan bahwa nilai signifikansi untuk variabel FI lebih dari 0,05 yakni sebesar 0,254 yang berarti faktor internal tidak berpengaruh signifikan terhadap kinerja UMKM. Hasil pengujian ini tidak sesuai dengan hipotesis satu yang diajukan, sehingga dapat disimpulkan bahwa hipotesis satu $\left(\mathrm{H}_{1}\right)$ ditolak. Hasil penelitian ini bertentangan dengan penelitian Munizu (2010) dan Hati dan Irawati (2017) yang menunjukkan bahwa faktor internal berpengaruh signifikan terhadap kinerja UMKM. Namun didukung dengan hasil penelitian Purwidiati dan Rahayu (2017) yang menemukan bahwa faktor internal tidak sepenuhnya berpengaruh positif terhadap kinerja Industri Kecil dan Menengah.

Penjelasan yang dapat dikemukakan terkait hasil pengujian tersebut adalah dimana dari aspek SDM, sebagian besar pelaku UMKM tidak melakukan penyeleksian pada saat penerimaan karyawan, serta tidak melakukan pembagian tugas juga terhadap karyawan. Untuk aspek keuangan, pelaku UMKM sektor industri cenderung memanfaatkan modal sendiri dalam berwirausaha dan tidak memiliki pembukuan.
Hal ini menyebabkan keuangan usaha dan keuangan pribadi sulit untuk dipisahkan, sehingga analisis kemampuan usaha dalam memperoleh laba yang diinginkan belum bisa optimal. Dari aspek produksi dan operasional, kurangnya ketersediaan mesin atau peralatan menyebabkan proses produksi tidak maksimal, dan ini tentunya berdampak pada aspek pasar dan pemasaran. Jika mengaitkan hasil ulasan tersebut dengan teori yang dikemukakan oleh Zimmerer et. al (2008), maka faktor internal yang dimaksud merupakan faktor internal negatif, yang mana merupakan faktor yang harus dihindari perusahaan agar tidak menghambat dalam pencapaian tujuan perusahaan.

Pengujian hipotesis kedua dalam penelitian ini bertujuan untuk membuktikan bahwa faktor eksternal berpengaruh signifikan terhadap kinerja UMKM. Faktor eksternal diuji dengan melihat tiga dimensi sebagai indikator yakni aspek kebijakan pemerintah, aspek sosial dan ekonomi, serta aspek peranan lembaga terkait. Pada tabel 1 dapat dilihat bahwa hasil pengujian hipotesis dua $\left(\mathrm{H}_{2}\right)$ menunjukkan nilai signifikansi variabel FE sebesar 0,000 yang mana lebih kecil dari 0,05. Ini berarti bahwa faktor eksternal berpengaruh signifikan terhadap kinerja UMKM. Maka dari itu, hasil pengujian ini sesuai dengan hipotesis dua yang diajukan, sehingga dapat disimpulkan bahwa hipotesis dua $\left(\mathrm{H}_{2}\right)$ diterima.

Hasil penelitian ini bertentangan dengan hasil penelitian dari Hati dan Irawati (2017) dan 
Purwidianti dan Rahayu (2017) yang menyatakan bahwa faktor eksternal tidak berpengaruh signifikan terhadap kinerja UMKM. Namun hasil penelitian ini didukung dengan hasil penelitian Munizu (2010) yang menyatakan bahwa faktor eksternal berpengaruh signifikan terhadap kinerja UMKM. Penjelasan yang dapat dikemukakan terkait hasil pengujian tersebut adalah dimana adanya kegiatan pembinaan dan pelatihan yang diberikan melalui dinas atau lembaga terkait sehingga menambah wawasan pelaku UMKM sektor industri dalam mengembangkan usahanya. Selain itu adanya kemudahan yang diberikan kepada pelaku umkm terkait ijin usaha. Zimmerer et. al (2008) mengemukakan bahwa faktor eksternal positif dapat membantu perusahaan dalam mencapai tujuannya.

\section{KESIMPULAN}

Hasil pengujian empiris membuktikan bahwa faktor internal tidak berpengaruh signifikan terhadap kinerja UMKM karena tidak dilakukannya penyeleksian dan pembagian tugas terhadap karyawan, kurangnya ketersediaan mesin dan peralatan, dan analisis kemampuan usaha dalam memperoleh laba yang diinginkan belum bisa optimal. Sedangkan, faktor eksternal berpengaruh signifikan terhadap kinerja UMKM karena adanya kegiatan pembinaan dan pelatihan yang diberikan melalui dinas/lembaga terkait, serta adanya kemudahan untuk akses ijin usaha.

\section{DAFTAR PUSTAKA}

Antara News. (2016). Gubernur Ingin UMKM Papua Barat Berdaya Saing. https://sultra.antaranews.com

Capps, C. J. \& Glissmeyer, M.D. (2012). Extending The Competitive Profile Matriz Using Internal Factor Evaluation and External Factor Evaluation Matrix Concepts, Journal of Applied Business Research, 28(5), 1059-1062.

David, F. 2. (2009). Strategic Management: Concepts and Cases, Twelth Edition, Pearson Prentice Hall, New Jersey.

Databoks. (2018). Industri Masih Mendominasi Kontribusi Perekonomian Indonesia. https://databoks.katadata.co.id.

Fibriyani, V. \& Mufidah, E. (2018). Pengaruh Faktor Eksternal dan Internal Terhadap Kinerja Usaha Mikro Kecil dan Menengah di Kota Pasuruan", Conference on Innovation and Application of Science and Technology, Universitas Widyagama Malang, 148-157.

Hati, S. W. \& Irawati, R. (2017). Faktor-Faktor yang Mempengaruhi Kinerja Usaha Mikro Kecil Menengah (UMKM) di Kota Batam, Proceedings of $5^{\text {th }}$ Applied Business and Engineering Conference, Kampus Politeknik Manufaktur Negeri Bangka Belitung.

Lembaga Penelitian UNIPA. (2012) "Laporan Pemetaan Lembaga Keuangan Mikdro \& Kajian Situasi Terkini tentang Akses ke Keuangan dan Pengembangan Usaha Mikro dan Kecil di Kabupaten Manokwari dan FakFak, Provinsi Papua Barat". Program Pembangunan berbasis Masyarakat Fase II: Implementasi Institusionalisasi Pembangunan Mata Pencaharian yang Lestari untuk Masyarakat Papua. ILO - PCdP2 UNDP.

Mokodompit, M. P. \& Usman, S. (2018) "The Use of Accounting Information on Micro to Medium Enterprises in Manokwari", Journal Research and Analysis: Accounting and Financial, 1(1), 28-33.

Munizu, M. (2010) "Pengaruh Faktor-Faktor Eksternal dan Internal Terhadap Kinerja Mikro dan Kecil (UMK) di Sulawesi Selatan", Jurnal Manajemen dan Kewirausahaan, 12(1), 33-41.

Pearce, J. A. \& Richard B. R. (2011) "Strategic Management Formulation, Implementation, and Control, Twelfth Edition", McGraw Hill, New York.

Purwidianti, W. \& Rahayu, T. S. M. (2017). Pengaruh Faktor Internal dan Eksternal Terhadap Kinerja Usaha Industri Kecil dan Menengah di Purworkerto Utara. Jurnal Kinerja, 19(2), 151-161.

Sandra, A. \& Purwanto, E. (2015) "Pengaruh Faktor-Faktor Eksternal dan Internal terhadap Kinerja Usaha Kecil dan Menengah di Jakarta", Business Management Journal, 11(1), 97-124.

Senzu, E. T. \& Ndebugri, H. (2018). Examining Budiness Performance of Micro, Small and Medium Scale Enterprise Through Accounting Records Keeping; Case Study in Ghana, Munich Personal RePEc Archive No. 84022. https://mpra.ub.unimuenchen.de.

Zimmerer, T. W. et al. (2008) "Kewirausahaan dan Manajemen Usaha Kecil, Edisi Kelima", Salemba Empat, Jakarta. 